Research Journal of Pharmacology 6 (1): 12-19, 2012

ISSN: $1815-9362$

(C) Medwell Journals, 2012

\title{
Investigating the Site of Action of an Aqueous Extract of Heliotropium indicum Linn (Boraginaceae) on Smooth Muscles
}

\author{
${ }^{1}$ George Asumeng Koffuor, ${ }^{2}$ Alex Boye, ${ }^{3}$ Patrick Amoateng, \\ ${ }^{1}$ Elvis O. Ameyaw and ${ }^{1}$ Alfred K. Abaitey \\ ${ }^{1}$ Department of Pharmacology, Faculty of Pharmacy and Pharmaceutical Sciences, \\ College of Health Sciences, Kwame Nkrumah University of Science and Technology, Kumasi, Ghana \\ ${ }^{2}$ Department of Medical Laboratory Technology, School of Physical Sciences, \\ University of Cape Coast, Cape-Coast, Ghana \\ ${ }^{3}$ Department of Pharmacology and Toxicology, School of Pharmacy, \\ College of Health Sciences, University of Ghana, Legon-Accra, Ghana
}

\begin{abstract}
Heliotropium indicum has various traditional medicinal uses such as treating abdominal pains, dysmenorrhoea, hypertension, convulsion, post-partum inflammatory disorders, wounds and infections and skin rashes. The aim of this study therefore is to find receptors that possibly mediate the activity of $H$. indicum as a means of finding explanation to some of its reported traditional uses. The effect of various concentrations of agonist drugs and an aqueous extract from the plant as well as the effects of these agonist drugs and the extract in the presence of specific reference antagonist drugs were established on isolated guinea-pig ileum, rabbit jejunum, rat uterus and rat anococcygeus preparations. Data obtained was analyzed using GraphPad Prism Version 5.0 for Windows. The extract caused dose-dependent contractions similar to the acetylcholine, methylcholine, carbamylcholine, nicotine, histamine and oxytocin used on the smooth muscle preparations studied. The contractions were significantly inhibited by atropine and hexamethonium, suggesting muscarinic and nicotinic activity, adrenaline and salbutamol, suggesting adrenoceptor activity and diclofenac sodium, suggesting the inhibition of synthesis and/or effect of products of COX such as prostaglandin. The extract was significantly stable to plasma cholinesterase. The receptor activity of $H$. indicum explains some of its traditional medicinal uses such as relieving abdominal pain, hypertension and impotence and sexual weakness.
\end{abstract}

Key words: Cholinesterase stabilty, hexamethonium, muscarinic activity, nicotinic activity, carbamylcholine, $\mathrm{COX}$

\section{INTRODUCTION}

Heliotropium indicum is an annual herb commonly known as the Cock's comb. It is usually associated with the moist rich soils of the lowland tropics near rivers and lakes on the roadsides and also in waste places (Holm et al., 1977). In Ghana, a cold infusion of the leaves has been used as an enema to stop abdominal pains and treat cataract; the juice from the leaves is squeezed into the eye to stop dizziness; decoction of the whole plant is used to treat convulsion in children; the roasted aerial parts of the plant together with certain ingredients are used as an enema for expulsion of clotted blood in a women who have recently given birth, the poultice of the leaves mixed with honey is externally applied to the penis to restore virility (Irvine, 1961), the juice from the mashed leaves is used as ear drops (Burkill, 1985) and the poultice is topically applied to swollen glands of the neck. Irvine (1961) had reported the use of the concoction of the leaves with clay as an anti-abortive agent among Asante women. Previous researches on this plant includes wound healing activity of $H$. indicum (Reddy et al., 2002; Diwan et al., 1982; Udupa et al., 1989) had reported that chloroform extract of $H$. indicum dose-dependently inhibited the carrageenan induced rat paw oedema and also showed anti-nociceptive activity in rats. Kugelman et al. (1976) isolated N-oxide of the alkaloid indicine from $H$. indicum and observed that it has significant anti-tumor activity. Crude hexane extract of $H$. indicum had antimicrobial activity against Mycobacterium tuberculosis (H37Ra) (Machinan et al., 2005). The extensive medicinal use of $H$. indicum is not paralleled by adequate scientific data there is therefore, the need to add to the existing scientific data to provide

Corresponding Author: George A. Koffuor, Department of Pharmacology,

Faculty of Pharmacy and Pharmaceutical Sciences, KNUST, Kumasi, Ghana 
some pharmacological evidence for its multi-medicinal uses, $H$. indicum extract is being investigated on isolated smooth muscle preparations.

\section{MATERIALS AND METHODS}

Plant collection: The aerial parts of Heliotropium indicum were collected from Buokrom, a suburb of the Ashanti region of Ghana in September, 2007 and authenticated by the Curator ( $\mathrm{Mr}$. Adator K. Brown) of the Department of Theoretical and Applied Biology, College of Sciences, KNUST where a voucher specimen (KNUST/BSC/F621) was deposited.

Preparation of extract: A $600 \mathrm{~g}$ quantity of the coarse powder was mixed with $5 \mathrm{~L}$ of water and warmed for $15 \mathrm{~min}$. The infusion was filtered to obtain a dark-brown filtrate, concentrated by evaporation over a hot water bath and later in a hot air-oven at $60^{\circ} \mathrm{C}$ until a constant weight was obtained. It was cooled in a desiccator to yield dark-brown solid extract which was named HIE.

Drugs and chemicals: Acetylcholine, nicotine, histamine, atropine, hexamethonium, mepyramine, methylcholine, carbamylcholine, physostigmine, noradrenaline and phentolamine were obtained from Sigma-Aldrich Inc., St. Louis, MO, USA. Oxytocin was obtained from Alliance Pharmaceuticals Ltd., UK and Salbutamol from Ernest Chemist, Accra, Ghana. These drugs were agonists and antagonists used in the study.

Experimental animals: Mature Sprague-Dawley rats, guinea-pigs and New Zealand White rabbits obtained from the animal house of the Department of Pharmacology, KNUST were used in this study. They animals were kept under ambient environmental conditions and had access to normal rat, guinea-pig and rabbit chow and water ad libitum.

Phytochemical evaluation: HIE was screened for phytochemical using standard techniques of plant metabolites as described by Sofowora (1993), Harbone (1998) and Trease and Evans (1989).

Isolated guinea-pig ileum: A guinea-pig was sacrificed and the ileum isolated as per the method described by Okpako and Taiwo (1984). It was mounted in Tyrode physiological solution maintained at $32^{\circ} \mathrm{C}$ with constant aeration using Corning-Eel, 850 air compressor (Evans Electroselenium Ltd., Halstead Essex England) in a Harvard tissue bath (Harvard Apparatus Ltd., Kent, UK). The baseline response was recorded by means of a pendular lever system with the frontal writing point moving on a white paper wound around a $30 \mathrm{~cm}$ diameter cylinder of Harvard kymograph (Harvard Apparatus Ltd., Kent, UK) revolving at a rate of $4 \mathrm{~mm} \mathrm{~min}^{-1}$. Acetylcholine $\left(1 \times 10^{-3}-2.6 \times 10^{-1} \mathrm{mg} \mathrm{mL} \mathrm{mL}^{-1}\right)$, histamine $\left(1 \times 10^{-3}-2.6 \times 10^{-1} \mathrm{mg} \mathrm{mL}^{-1}\right)$, nicotine $\left(1 \times 10^{-3}-2.6 \times 10^{-1} \mathrm{mg}\right.$ $\left.\mathrm{mL}^{-1}\right)$ and $\mathrm{HIE}\left(2 \times 10^{-2}-5.12 \mathrm{mg} \mathrm{mL}^{-1}\right)$ was applied on the guinea-pig ileum and the contractile responses recorded using $3 \mathrm{~min}$ time cycle and a $30 \mathrm{sec}$ contact time. The procedure was repeated four times.

\section{Determination of site of action of $\mathrm{HIE}$ on the guinea-pig \\ ileum: A complete dose-response tracings of acetylcholine $\left(8 \times 10^{-5}-1.3 \times 10^{-3} \mathrm{mg} \mathrm{mL}^{-1}\right)$ was} established using the isolated guinea-pig ileum. A 70-75\% sub-maximal response produced by acetylcholine $\left(6.4 \times 10^{-4} \mathrm{mg} \mathrm{mL}^{-1}\right)$ was selected. Equipotent responses to the submaximal response of acetylcholine produced by nicotine $\left(4 \times 10^{-4} \mathrm{mg} \mathrm{mL}^{-1}\right)$, histamine $\left(3.2 \times 10^{-4} \mathrm{mg} \mathrm{mL}^{-1}\right)$ and HIE $\left(2.7 \mathrm{mg} \mathrm{mL}^{-1}\right)$ were established and matched. Attempts were made to establish the equipotent responses again in the presence of hexamethonium $\left(0.005 \mathrm{mg} \mathrm{mL}^{-1}\right)$, atropine $\left(1 \times 10^{-4} \mathrm{mg} \mathrm{mL}^{-1}\right)$, mepyramine $\left(2 \times 10^{-2} \mathrm{mg} \mathrm{mL}^{-1}\right)$ and contractile responses recorded and compared. The procedure was repeated 4 times.

Test for stability of HIE to plasma cholinesterase: A complete dose-response tracings of acetylcholine was established and a sub-maximal response $(70 \%$ of the maximum response) given by $1 \times 10^{-6} \mathrm{mg} \mathrm{mL}^{-1}$ was chosen. Equipotent responses for methylcholine $\left(1 \times 10^{-6} \mathrm{mg} \mathrm{mL}^{-1}\right)$ carbamylcholine $\left(3 \times 10^{-6} \mathrm{mg} \mathrm{mL}^{-1}\right)$ and HIE ( $8.5 \mathrm{mg} \mathrm{mL}^{-1}$ ) were established. Ten test tubes were labelled I-X and treated as shown in Table 1.

While 10-fold sub-maximal dose of acetylcholine and equipotent doses of methylcholine, carbamylcholine and HIE were added to test tubes I-IV, respectively and made up with distilled water up to $10 \mathrm{~mL}$ to serve as controls. To the tenfold dose of acetylcholine (test tube V), methylcholine (test tube VI), carbamylcholine (test tube VII) and the HIE (test tube VIII) was added 3 drops of blood (source of cholinesterase) and then made up to $10 \mathrm{~mL}$ with distilled water.

To test tube IX (control), 3 drops of blood and $5 \mathrm{~mL}$ distilled water were added, boiled for $5 \mathrm{~min}$ and cooled before the addition of the 10 -fold dose of acetylcholine. It was then made up with distilled water to $10 \mathrm{~mL}$. To confirm that cholinesterase was responsible for the expected inhibitions, 3 drops of blood and $1 \mathrm{~mL}$ of physostigmine $\left(5 \times 10^{-2} \mathrm{mg} \mathrm{mL}^{-1}\right)$ was added to test tube $\mathrm{X}$ before the addition of the 10 -fold dose of acetylcholine. It was then made up with distilled water to $10 \mathrm{~mL}$. The test 
Res. J. Pharmacol., 6 (1): 12-19, 2012

\begin{tabular}{|c|c|c|c|c|c|c|c|c|c|c|}
\hline Test tubes & I & II & III & IV & $\mathrm{V}$ & $\mathrm{VI}$ & VII & VIII & $\mathrm{LX}$ & $\mathrm{X}$ \\
\hline Acetylcholine & $0.2 \mathrm{~mL}$ & - & - & - & $0.2 \mathrm{~mL}$ & - & - & - & $0.2 \mathrm{~mL}$ & $0.2 \mathrm{~mL}$ \\
\hline Methylcholine & - & $0.5 \mathrm{~mL}$ & - & - & - & $0.5 \mathrm{~mL}$ & - & - & - & - \\
\hline Carbamy lcholine & - & - & $0.5 \mathrm{~mL}$ & - & - & - & $0.5 \mathrm{~mL}$ & - & - & - \\
\hline HIE & - & - & - & $0.5 \mathrm{~mL}$ & - & - & - & $0.5 \mathrm{~mL}$ & - & - \\
\hline Blood & - & - & - & - & 3 drops & 3 drops & 3 drops & 3 drops & 3 drops* & 3 drops \\
\hline Physostigmine & - & - & - & - & - & - & - & - & & $1 \mathrm{~mL}$ \\
\hline Distilled water & $10 \mathrm{~mL}$ & $10 \mathrm{~mL}$ & $10 \mathrm{~mL}$ & $10 \mathrm{~mL}$ & $10 \mathrm{~mL}$ & $10 \mathrm{~mL}$ & $10 \mathrm{~mL}$ & $10 \mathrm{~mL}$ & $10 \mathrm{~mL}$ & $10 \mathrm{~mL}$ \\
\hline
\end{tabular}

*The blood was added to distilled water, boiled and cooled before adding $10 \times$ volume of acetylcholine that yielded the sub-maximal dose

tubes were incubated for $15 \mathrm{~min}$ in water bath at $37^{\circ} \mathrm{C}$ which is the optimum temperature for cholinesterase activity. After the incubation period, $1 \mathrm{~mL}$ of each drug equivalent to the selected dose in the respective testtubes were administered onto the mounted isolated guinea-pig ileum preparation in succession and the doseresponse tracings obtained were analyzed. The procedure was repeated three times.

Isolated rabbit jejunum: A rabbit was sacrified and the jejunum isolated as earlier described by Okpako and Taiwo (1984). It was mounted in a Harvard tissue bath in Ringer Locke physiological maintained at $37^{\circ} \mathrm{C}$ with constant aeration. The baseline response was recorded by means of a pendular lever system with the frontal writing point moving on a white paper wound around a $30 \mathrm{~cm}$ diameter cylinder of Harvard kymograph revolving at a rate of $8 \mathrm{~mm} \mathrm{~min}^{-1}$. The contractile effects of acetylcholine $\left(1 \times 10^{-4}-3.2 \times 10^{-2} \mathrm{mg} \mathrm{mL}^{-1}\right)$, nicotine $\left(1.25 \times 10^{-2} \mathrm{mg} \mathrm{mL}^{-1}\right)$ and HIE $\left(3 \times 10^{-1}-34 \mathrm{mg} \mathrm{mL}^{-1}\right)$ were established and the reestablished in the presence of atropine $\left(8.3 \times 10^{-8} \mathrm{mg} \mathrm{mL}^{-1}\right)$ and hexamethonium $\left(0.01 \mathrm{mg} \mathrm{mL}^{-1}\right)$. A time cycle of $3 \mathrm{~min}$ and a contact time of $30 \mathrm{sec}$ was used. The procedure was repeated four times.

Isolated rat uterus: The two horns of the uterus of a female Sprague-Dawley rat were isolated and mounted in a Harvard tissue bath in De Jalon's physiological solution maintained at $32^{\circ} \mathrm{C}$ as previously described by Okpako and Taiwo (1984). The two horns were separated and freed from fat and connective tissues and each was cut open longitudinally. A strip of the horn (about $2-3 \mathrm{~cm}$ ) was cut out. One end of the isolated uterine strip and mounted on the tissue holder in the organ bath containing De Jalon's physiological solution (maintained at $32^{\circ} \mathrm{C}$ and constantly aerated) with a piece of cotton thread while the other end was attached to a pendular lever system with the frontal writing point moving on a white paper wound around a $30 \mathrm{~cm}$ diameter cylinder of Harvard kymograph revolving at a rate of $4 \mathrm{~mm} \mathrm{~min}$.

After $1 \mathrm{~h}$, the baseline response was recorded. Responses of oxytocin $\left(1 \times 10^{-3}-6.67 \times 10^{-2} \mathrm{mg} \mathrm{mL} \mathrm{m}^{-1}\right)$, acetylcholine $\left(1 \times 10^{-3}-3.2 \times 10^{-2} \mathrm{mg} \mathrm{mL} \mathrm{m}^{-1}\right)$ and $\mathrm{HIE}$ $\left(1.3 \times 10^{-1}-17.1 \mathrm{mg} \mathrm{mL}^{-1}\right)$ applied on the tissue preparation and these in the presence of reference antagonists drugs adrenaline $\left(1 \times 10^{-3} \mathrm{mg} \mathrm{mL}^{-}\right)$, salbutamol $\left(4.2 \times 10^{-}\right.$mg $\left.\mathrm{mL}^{-1}\right)$, atropine $\left(4.2 \times 10^{-4} \mathrm{mg} \mathrm{mL}^{-1}\right)$ and diclofenac sodium $\left(1.7 \times 10^{-1} \mathrm{mg} \mathrm{mL}^{-1}\right)$. The contractile responses recorded using 3 min time cycle and a $30 \mathrm{sec}$ contact time. The procedure was repeated 4 times.

Isolated rat anococcygeus: This method was previously described by Gillespie (1972) with some modification. The abdomen of a male rat was opened in the mid-line, the pelvis split and the bladder and urethra removed. Care was taken in clearing the lower part of the urethra to avoid damage to the ventral bar of the muscle, the only region lying ventral to the colon. The colon was then cut through at the pelvic brim, the portion pulled forward and the delicate connective tissue behind cleared until the anococccygeus muscles came into view. The muscle was isolated with the extrinsic nerve intact. The ventral bar was cut through and each muscle mounted in a $20 \mathrm{~mL}$ tissue bath containing Kreb's solution at $32^{\circ} \mathrm{C}$. The tissue was aerated with $95 \% \mathrm{O}_{2}+5 \% \mathrm{CO}_{2}$. The anococcygeus was tied anteriorly to a hook in the tissue bath while the posterior end was tied to a lever system with a writing pointer on a white kymograph paper wound around a drum revolving at a rate of $4 \mathrm{~mm} \mathrm{~min}^{-1}$. Base line tracings were obtained. The responses of noradrenaline $\left(210^{-7}\right.$ $\left.2 \times 10^{-5} \mathrm{mg} \mathrm{mL}^{-1}\right)$, acetylcholine $\left(4 \times 10^{-7}-4 \times 10^{-5} \mathrm{mg} \mathrm{mL}^{-1}\right)$ and $\mathrm{HIE}\left(1-32 \mathrm{mg} \mathrm{mL}^{-1}\right)$ and these in the presence of phentolamine $\left(1 \times 10^{-6} \mathrm{mg} \mathrm{mL}^{-1}\right)$ and atropine $\left(4 \times 10^{-6} \mathrm{mg} \mathrm{mL}^{-1}\right)$ were recorded.

Statistical analysis: GraphPad Prism Version 5.0 for Windows (GraphPad Software, San Diego, CA, USA) was used for all statistical analyses. Data are presented as mean \pm SEM and analyzed by one-way ANOVA followed by Bonferroni's multiple comparisons test (post test). The $\mathrm{p} \leq 0.05$ was considered statistically significant in all analysis.

\section{RESULTS AND DISCUSSION}

Phytochemical screening: Phytochemical screening of HIE showed the presence of alkaloids, cyanogenic glycosides, tannins, saponins and steroids. 


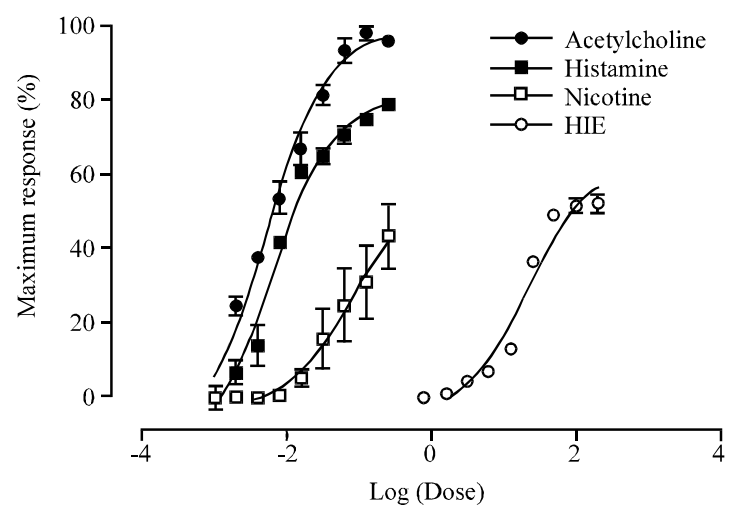

Fig. 1: Log-dose response curves of acetylcholine, histamine and nicotine at doses of $1 \times 10^{-3}$ $2.6 \times 10^{-1} \mathrm{mg} \mathrm{mL}^{-1}$ and $\mathrm{HIE}\left(2 \times 10^{-2}-5.12 \mathrm{mg} \mathrm{mL}^{-1}\right)$ on the isolated guinea-pig ileum preparation. Each point represents the mean $\pm \operatorname{SEM}(n=4)$

Table 2: The inhibitory effect (\%) of atropine, hexamethonim and mepyramine on the contractile activity of acetylcholine, nicotine, histamine and HIE

\begin{tabular}{|c|c|c|c|c|}
\hline \multirow[b]{2}{*}{ Antagonist } & \multicolumn{4}{|l|}{ Agonists } \\
\hline & Acetylcholine & Nicotine & Histamine & $\mathrm{HEE}$ \\
\hline Atropine & $72.6 \pm 0.9597$ & $3.0 \pm 0.5774$ & $3.0 \pm 0.91290$ & $34.8 \pm 0.1999$ \\
\hline Hexamethonium & $2.3 \pm 0.8539$ & $86.2 \pm 0.9950$ & $1.25 \pm 0.7500$ & $38.9 \pm 1.5900$ \\
\hline Mepyramine & $2.3 \pm 0.6292$ & $3.8 \pm 0.8539$ & $65.7 \pm 0.11590$ & $0.0 \pm 0.0000$ \\
\hline
\end{tabular}

Effect of HIE on the isolated guinea-pig ileum: HIE produced dose-dependent contractions of the isolated guinea-pig ileum comparable to acetylcholine, histamine and nicotine (Fig. 1). The contractile effects were inhibited by of atropine and hexamethonium but not mepyramine. The percentage inhibitions are as shown in Table 2. HIE showed stability to plasma cholinesterase comparable to those of carbamylcholine and methylcholine (Fig. 2).

Effect of HIE on the rabbit jejunum: HIE produced biphasic effect on the jejunum; relaxing the rhythmic contractions of the jejunum at lower concentrations and dose-dependent contractions at higher doses (0.3-34.1 $\left.\mathrm{mg} \mathrm{mL}^{-1}\right)$. The effects of HIE in the contractile phase was similar to effects of acetylcholine and nicotine. Atropine and hexamethonium inhibited the contractile effects of HIE (Fig. 3).

Effect of HIE on the isolated rat uterus: HIE produced dose-dependent myometrial contractions on the isolated rat uterus preparations similar to those produced by acetylcholine and oxytocin (Fig. 4). The myometrial contractions caused by $\mathrm{HIE}$ and acetylcholine were inhibited by atropine. These drugs were physiologically

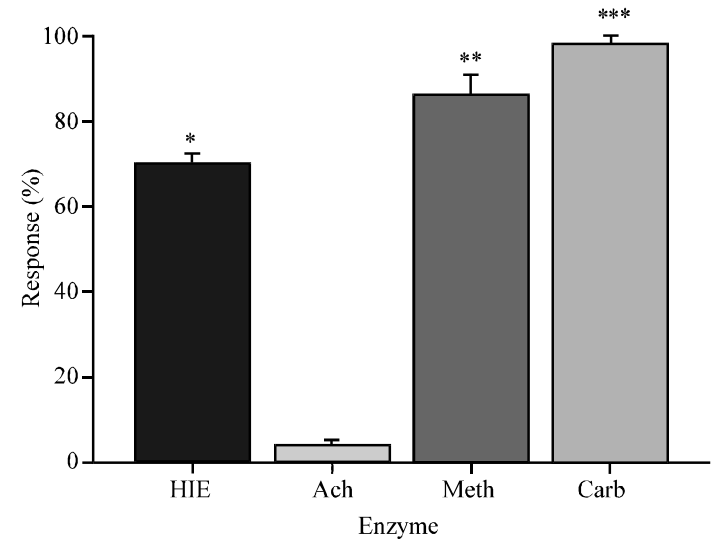

Fig. 2: The contractile effects of acetylcholine $\left(1 \times 10^{-6} \mathrm{mg}\right.$ $\left.\mathrm{mL}^{-1}\right)$, methylcholine $\left(1 \times 10^{-6} \mathrm{mg} \mathrm{mL}^{-1}\right)$, carbamylcholine $\left(3 \times 10^{-6} \mathrm{mg} \mathrm{mL}^{-1}\right)$ and $\mathrm{HIE}$ $\left(8.5 \mathrm{mg} \mathrm{mL}^{-1}\right)$ on the guinea-pig isolated ileum in the presence of cholinesterase (enzyme). Each column is the mean \pm SEM $(n=3)$. The degree of significance in activity in the presence of cholinesterase: ${ }^{* * *} \mathrm{p}<0.001$ (highly significant), ${ }^{* *} \mathrm{p}<0.01$ (very significant), ${ }^{*} \mathrm{p}<0.05$ (significant)

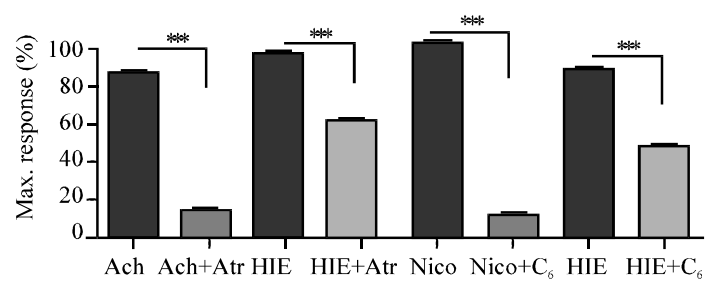

Fig. 3: Effect of acetylcholine $\left(1 \times 10^{-4}-3.2 \times 10^{-2} \mathrm{mg} \mathrm{mL}^{-1}\right)$, nicotine $\left(1.25 \times 10^{-2} \mathrm{mg} \mathrm{mL}^{-1}\right)$ and $\mathrm{HIE}\left(3 \times 10^{-1}\right.$ $34 \mathrm{mg} \mathrm{mL}^{-1}$ ) on the rabbit isolated jejunum in the presence of atropine $\left(8.3 \times 10^{-8} \mathrm{mg} \mathrm{mL}{ }^{-1}\right)$ and hexamethonium $\left(0.01 \mathrm{mg} \mathrm{mL}^{-1}\right)$. Each column is the mean $\pm \operatorname{SEM}(n=4)$. Inhibitions of responses: HIE by atropine, ${ }^{* *} \mathrm{p}<0.01$; acetylcholine by atropine, ${ }^{* * *} \mathrm{p}<0.001, \mathrm{HIE}$ by hexamethonium, ns; $\mathrm{p}>0.05$, nicotine by $\mathrm{C}_{6}{ }^{* *} \mathrm{p}<0.01$

antagonized by adrenaline (Fig. 5). The myometrial contractions caused by HIE and oxytocin were inhibited by salbutamol but the myometrial contractions caused by $\mathrm{HIE}$ (but not oxytocin) was inhibited by diclofenac sodium (Fig. 6).

Effect of HIE on the isolated rat anococcygeus muscle: HIE produced a concentration-dependent contraction of the isolated rat anococcygeus muscle and these contractions were competitively inhibited by atropine and phentolamine (seen as a parallel shift of the curve to the 


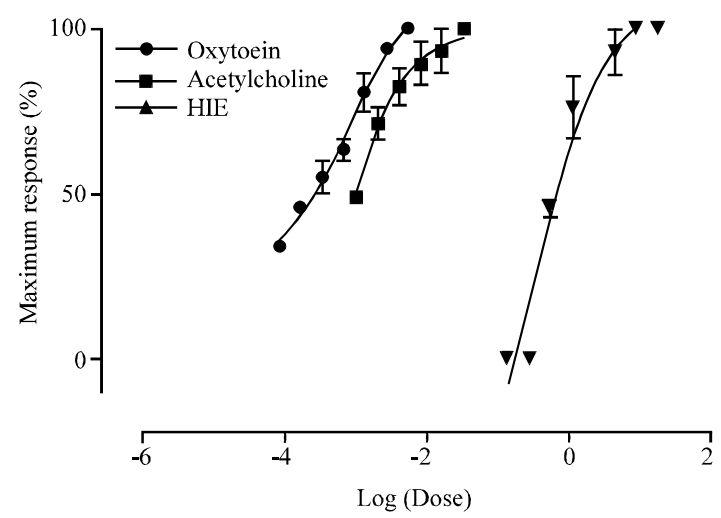

Fig. 4: Log-dose response curves of oxytocin $\left(8.3 \times 10^{-5}\right.$ $\left.5.3 \times 10^{-3} \mathrm{IU} \mathrm{mL}^{-1}\right)$, acetylcholine $\left(1 \times 10^{-3}-3.2 \times 10^{-2}\right.$ $\left.\mathrm{mg} \mathrm{mL} \mathrm{m}^{-1}\right)$ and HIE $\left(0.13-17.1 \mathrm{mg} \mathrm{mL}^{-1}\right)$ on the isolated non pregnant rat uterus. Each point is the mean $\pm \operatorname{SEM}(n=5)$

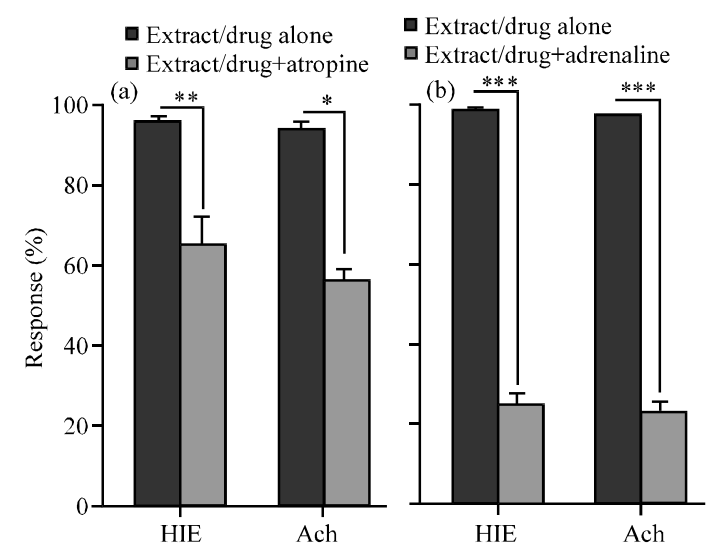

Fig. 5: Inhibitions of the myometrial contractions of HIE $\left(1.3 \times 10^{-1}-17.1 \mathrm{mg} \mathrm{mL}^{-1}\right)$ and acetylcholine $\left(1.3 \times 10^{-1}-17.1 \mathrm{mg} \mathrm{mL}^{-1}\right)$ by atropine $\left(4.2 \times 10^{-4} \mathrm{mg}\right.$ $\left.\mathrm{mL}^{-1}\right)$ and adrenaline $\left(1 \times 10^{-3} \mathrm{mg} \mathrm{mL}^{-1}\right)$ on the isolated rat uterus. Each column is the mean $\pm \mathrm{SEM}$ $(\mathrm{n}=4)$. Inhibition of responses: HIE by atropine, ${ }^{* *} \mathrm{p}<0.01$; acetylcholine by atropine, ${ }^{*} \mathrm{p}<0.05$, HIE by adrenaline, ${ }^{* * *} \mathrm{p}>0.001$, acetylcholine by adrenaline, ${ }^{* * *} \mathrm{p}<0.001$

right). Acetycholine and noradrenaline also produced contractile responses that were also competitively inhibited by atropine and phentolamine, respectively (Fig. 7 and 8). The purpose of this study was to provide pharmacological bases and possible mechanism (s) of action of an aqueous extract from $H$. indicum on isolated smooth muscles, thus supporting some of it traditional uses in Ghana. A repertoire of tissues was employed in the study in order to assess as many receptors as possible as well as providing direct evidence to the

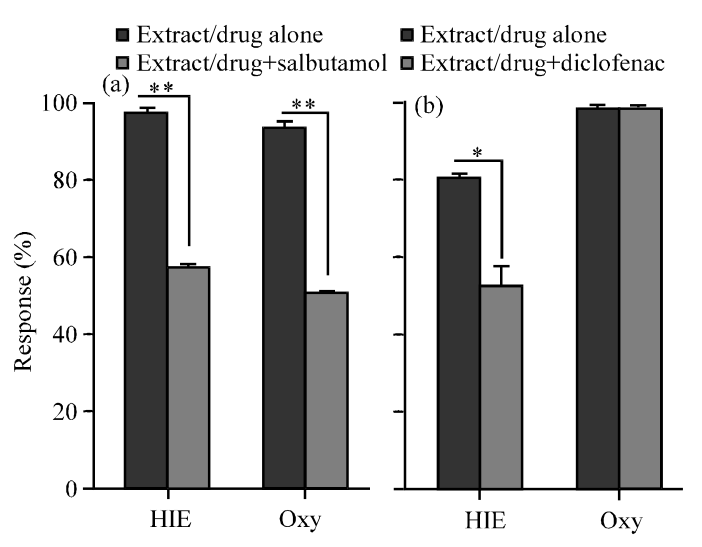

Fig. 6: Inhibitions of the myometrial contractions of HIE $\left(1.3 \times 10^{-1}-17.1 \mathrm{mg} \mathrm{mL}^{-1}\right)$ and oxytocin $\left(1 \times 10^{-3}\right.$ $\left.6.67 \times 10^{-2} \mathrm{mg} \mathrm{mL}^{-1}\right)$ by salbutamol $\left(4.2 \times 10^{-4} \mathrm{mg}\right.$ $\left.\mathrm{mL}^{-1}\right)$ and diclofenac sodium $\left(1.7 \times 10^{-1} \mathrm{mg} \mathrm{mL}^{-1}\right)$ on the isolated rat uterus. Each column is the mean $\pm \operatorname{SEM}(n=4)$. Inhibition of responses: HIE by salbutamol, ${ }^{* *} \mathrm{p}<0.01$; oxytocin by salbutamol, ${ }^{* *} \mathrm{p}<0.01$, HIE by diclofenac, ${ }^{*} \mathrm{p}>0.05$, oxytocin by diclofenac, ns; $p>0.05$

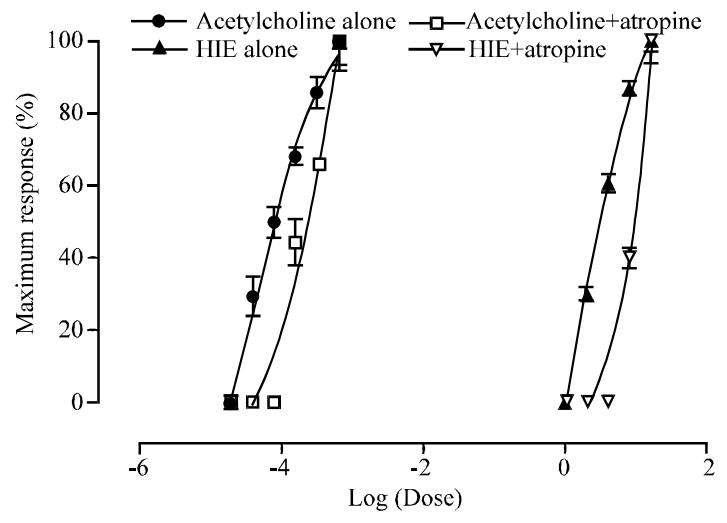

Fig. 7: The contractile effects of acetylcholine $\left(4 \times 10^{-7}\right.$ $\left.4 \times 10^{-5} \mathrm{mg} \mathrm{mL}^{-1}\right)$ and $\mathrm{HIE}\left(1-32 \mathrm{mg} \mathrm{mL}^{-1}\right)$ in the absence of and in presence of atropine $\left(4 \times 10^{-6} \mathrm{mg}\right.$ $\mathrm{mL}^{-1}$ ). The parallel shift of the acetylcholine and HIE curves to the right indicates in the presence of atropine indicates competitive inhibition

ethnopharmacological use of the plant. The isolated guinea-pig ileum is a low tone tissue which has muscarinic (Giraldo et al., 1988; Bolton and Zholos, 1997), histaminic (Bertaccini et al., 1979; Barker and Ebersole, 1982), opioid (Campbell et al., 1989) and neurokinin (Nguyen-Le et al., 1996) receptors. Because the autonomic ganglion (which has nicotinic receptors) is so close to the tissue, an isolated ileum will have nicotinic receptor activity. 


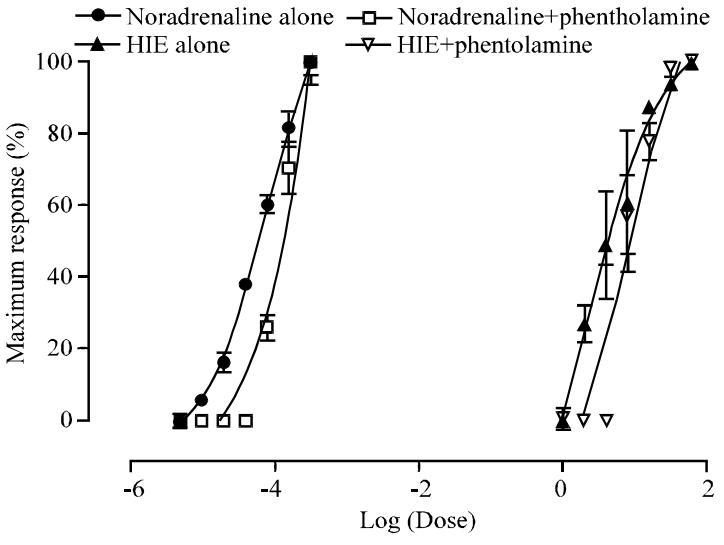

Fig. 8: The contractile effects of noradrenaline $\left(2 \times 10^{-7}\right.$ $\left.2 \times 10^{-5} \mathrm{mg} \mathrm{mL}^{-1}\right)$ and $\mathrm{HIE}\left(1-32 \mathrm{mg} \mathrm{mL}^{-1}\right)$ in the absence of and in presence of phentolamine $\left(1 \times 10^{-6} \mathrm{mg} \mathrm{mL}{ }^{-1}\right)$. The parallel shift of the noradrenaline and HIE curves to the right indicates in the presence of phentolamine indicates competitive inhibition

On the isolated guinea pig ileum, the contractile effects produced by HIE was inhibited by atropine; a competitive muscarinic-receptor antagonist (Karita et al., 1995; Rosenfeld and Loose, 2006) and hexamethonium; a ganglionic blocker (Finnerty and Freis, 1950; Sonoyama et al., 2000) but not by mepyramine; a competitive histaminic-receptor antagonist. The inhibitory effect of atropine and hexamethonium suggests that HIE has chemical principles with muscarinic and nicotinicreceptor activity.

The non-inhibitory effect of mepyramine suggests that HIE is devoid of histaminic properties. The extract showed stability to cholinesterase comparable to carbamycholine and methylcholine. The rabbit jejunum unlike the guinea-pig ileum is a high tone tissue which has adrenoceptors (Nakahata et al., 1978), muscarinic and opioid (Cosola et al., 2006) receptor among other. HIE produced relaxation of spontaneous contractions at lower doses and concentration-dependent contractions (inhibited by atropine) at higher dose.

This biphasic characteristic indicates that HIE has adrenoceptor activity (mediates the relaxation) and muscarinic-receptor activity (mediates the contraction) confirming the muscarinic as well as unfolding the adrenergic effects of HIE. To further evaluate the adrenergic effects of HIE, the rat anococcygeus muscle preparation was employed. The autonomic innervation of the rat anococcygeus muscle contains noradrenergic, cholinergic and Non-Adrenergic Non-Cholinergic (NANC) components (Rand and Li, 1993). Stimulation of sympathetic nerves causes noradrenergically mediated contractions (Gillespie, 1972). Contractions of the rat anococcygeus muscle elicited by acetylcholine can be attributed to activation of postjunctional muscarinic receptors (Gillespie, 1972). On the isolated rat anococcygeus muscle, HIE produced concentrationdependent contractile effect which was competitive inhibited by atropine and phentolamine (a non-selective $\alpha$-adrenoceptor antagonist) suggesting that the extract may have chemical constituents with muscarinic and possibly $\alpha$-adrenoceptor agonist activity.

To lend some information to support or prove otherwise the traditional uses of the plant in conditions involving the uterus assessment of HIE on the isolated rat uterus was conducted. The isolated rat uterus has among a number muscarinic (Choppin et al., 1999), adrenergic (Paton, 1968) and oxytocic (Engstrom et al., 2000) receptors. The assessment of HIE on the isolated rat uterus was conducted to lend some information to support or prove otherwise the traditional uses of the plant in conditions involving uterus.

The extract produced concentration-dependently myometrial contraction just as acetycholine and oxytocin and these contractions were inhibited by atropine, adrenaline (non-selective adrenoceptor agonist), salbutamol ( $\beta_{2}$-adrenoceptor agonist) and diclofenac (cyclooxygenase enzyme inhibitor). These suggest that the contractile effect of HIE may be mediated via a cholinergic mechanism, a blockade of adrenoceptors (possibly $\beta_{2}$-adrenoceptors) and possibly through the enhancement of prostaglandin synthesis (Mironneau et al., 1984). One traditional use of $H$. indicum is the relief of abdominal pain. One cause of abdominal pain is the inability to empty the filled urinary bladder possible due to a malfunctioning urinary bladder due to neurologic dysfunction or insult emanating from internal or external trauma, disease or injury termed neurogenic bladder. The muscarinic activity suggests that the plant extract of can be used to assist bladder emptying (Chess-Williams, 2002).

Furthermore, the use of HIE for abdominal pain may stem from its ability to activate the $\alpha$-adrenoceptors which in effect lead to decreased motility and spasms (source of pain such as abdominal cramps) of the GIT as well as visceral organs. More so, the leaves of $H$. indicum can serve as home remedy for poisoning arising from pesticides such as D-tubocurarine that act by depleting $\mathrm{ACh}$ from the neuromuscular junction. Activation of the parasympathetic nervous system innervating the penis produces cGMP and thus gives rise to an erection (Kandeel et al., 2001). Muscarinic-receptor stimulation by 
acetylcholine increases arterial flow, cavernous smooth muscle relaxation and venous occlusion (Stief et al., 1989). The stimulation of spinal cord acetylcholine receptors has been reported to facilitate ejaculation (Guttman and Walsh, 1970; Chapelle et al., 1993; Vargas et al., 2004). Induction of prostaglandin synthesis causes vasodilatation of penile arteries which enhances erection (Minhas et al., 2001). This effect may support its traditional use of externally applying to the penis to restore virility (Irvine, 1960). Muscarinic activity on the myocardium which results in a negative ionotropic and chronotropic effect could contribute immensely to reducing blood pressure; the product of cardiac output and total peripheral resistance.

By the negative effect, cardiac output will be reduced. This could lend an explanation to the use of the plant as an antihypertensive. The muscarinic agonist activity and enhanced synthesis/release of prostaglandin of HIE augmented by its anti-sympathetic activity on $\beta_{2^{-}}$ receptors may again support its use as an enema for expulsion of clotted blood in women who have recently given birth. Clots of blood in the uterus after childbirth (post-labour disorder) may also result in abdominal pain. Further, in vitro research is needed to provide a direct and clearer mechanism of action of the contractile effects of the extract on the uterus. Thus, the use of plant in pregnant women must be done with caution. The use of $H$. indicum in dysmenorrhea, post-partum inflammatory disorders, wounds and infections and skin rashes could be due it its anti-inflammatory (Srinivas et al., 2000) and antimicrobial activity (Dash and Murthy, 2011) which it has been reported. Phytochemical identified are in conformity to that found in previous studies (Zhao et al., 1989).

\section{CONCLUSION}

In the study, the extract of $H$. indicum has chemical constituents that have stimulatory effects at the muscarinic and nicotinic receptors, $\alpha$ and $\beta$-adrenoceptors and possible enhance prostaglandin synthesis. These effects explain some of its reported traditional uses in Ghana although, further studies are recommended to establish its safety for use.

\section{ACKNOWLEDGEMENTS}

The researchers wish to express their gratitude to Mr. Thomas Ansah of the Department of Pharmacology, KNUST and Mr. Adator K. Brown of the Department of Theoretical and Applied Biology, College of Sciences, KNUST for their technical assistance.

\section{REFERENCES}

Barker, L.A. and B.J. Ebersole, 1982. Histamine $\mathrm{H}_{2}-$ receptors on guinea-pig ileum myenteric plexus neurons mediate the release of contractile agents. JPET, 221: 69-75.

Bertaccini, G., E. Molina, L. Zappia and J. Zseli, 1979. Histamine receptors in the guinea-pig ileum. NaunynSchmiedeberg's Arch. Pharmacol., 309: 65-68.

Bolton, T.B. and A.V. Zholos, 1997. Activation of $\mathrm{M}_{2}$ muscarinic receptors in guinea-pig ileum opens cationic channels modulated by $\mathrm{M}_{3}$ muscarinic receptors. Life Sci., 60: 1121-1128.

Burkill, H.M., 1985. The useful plants of west tropical Africa. Vol. 1, Royal Botanic Gardens, Kew (K).

Campbell, B.G., M.W. Scherz, J.F. Keana and E. Weber, 1989. Sigma receptors regulate contractions of the guinea pig ileum longitudinal muscle/myenteric plexus preparation elicited by both electrical stimulation and exogenous serotonin. J. Neurosci., 9: 3380-3391.

Chapelle, P.A., F. Blanquart, A.J. Puech and J.P. Hold, 1993. Treatment of an ejaculation in the total paraplegic by subcutaneous injections of physostigmine. Paraplegia, 21: 30-36.

Chess-Williams, R., 2002. Muscarinic receptors of the urinary bladder: Detrusor, urothelial and prejunctional. Autonomic Autacoid Pharmacol., 22: 133-145.

Choppin, A., G.J. Stepan, D.N. Loury, N. Watson and R.M. Eglen, 1999. Characterization of the muscarinic receptor in isolated uterus of sham operated and ovariectomized rats. Br. J. Pharmacol., 127: 1551-1558.

Cosola, C., M. Albrizio, A.C. Guaricci, M.A. De Salvia, A. Zarrilli, R.L. Sciorsci and R. Minoia, 2006. Opioid agonist/antagonist effect of naloxone in modulating rabbit jejunum contractility in vitro. J. Physiol. Pharmacol., 57: 439-449.

Dash, G.K. and P.N. Murthy, 2011. Studies on wound healing activity of Heliotropium indicum Linn. leaves on rats. ISRN Pharmacol., 2011: 1-8.

Diwan, P.V., D. Tilloo and D.R. Kulkarni, 1982. Influence of Tridax procumbens on wound healing. Indian J. Med. Res., 75: 460-464.

Engstrom, T., P. Bratholm, N.J. Christensen and H. Vilhardt, 2000. Effect of oxytocin receptor blockade on rat myometrial responsiveness to prostaglandin F2á1. Biol. Reprod., 63: 1443-1449.

Finnerty, F.A. and E.D. Freis, 1950. Experimental and clinical evaluation in man of hexamethonium (C6) a new ganglionic blocking agent. Circulation, 2: 828-836. 
Gillespie, J.S., 1972. The rat anococcygeus muscle and its response to nerve stimulation and to some drugs. $\mathrm{Br}$. J. Pharmacol., 45: 404-416.

Giraldo, E., M.A. Vigano, R. Hammer and H. Ladinsky, 1988. Characterization of muscarinic receptors in guinea pig ileum longitudinal smooth muscle. Mol. Pharmacol., 33: 617-625.

Guttman L. and J.J. Walsh, 1970. Prostigmin assessment test of fertility in spinal man. Paraplegia, 9: 39-43.

Harborne, J.B., 1998. Phytochemical methods: A guide to modern techniques of plant analysis. 3rd Edn., Springer, London.

Holm, L.G., D.L. Pluknett, J.V. Pancho and J.P. Herberger, 1977. The world's worst weeds: Distribution and biology.. HI University of Hawaii Press, Honolulu, pp: 609.

Irvine, J.R., 1961. Woody plants of ghana. 2nd Edn., Oxford University Press, London, pp: 58.

Kandeel, F.R., V.K.T. Koussa and R.S. Swerdloff, 2001. Male sexual function and its disorders: physiology, pathophysiology, clinical investigation, and treatment. Endocr. Rev., 22: 342-388.

Karita, K., H. Takahashi, T. Yasui and H. Izumi, 1995. Effects of the autonomic ganglion blocking agent hexamethonium on vasodilator responses mediated by the parasympathetic ganglion on the chorda tympani pathway of the cat. J. Auton. Nerv. Syst., 52: 65-70.

Kugelman, M., W.C. Liu, M., Axelrod, T.J. McBride and K.V. Rao, 1976. Indicine-N-oxide: The antitumor principle of Heliotropium indicum. Lloydia, 39: 125-128.

Machinan, T., J. Korth, L. Boonsom, L. Saisunee and G. Stephen, 2005. Composition and antituberculosis activity of the volatile oil of Heliotropium indicum Linn growing in Phitsanulok, Thailand. Flavour Fragrance J., 21: 265-267.

Minhas, S., J. Cartledge and I. Eardley, 2001. The pathophysiological role of prostaglandins in penile erection. Expert Opin. Pharmacothe., 2: 799-811.

Mironneau, C., J. Mironneau and J.P. Savineau, 1984. Maintained contractions of rat uterine smooth muscle incubated in a $\mathrm{Ca}^{2+}$-free solution. Br. J. Pharmacol., 82: 735-743.

Nakahata, N., Y. Takagi, E. Watanabe and T. Suzuki, 1978. Adrenergic beta 1 - and beta 2-receptors in the isolated rabbit jejunum and ileum. Fukushima J. Med. Sci., 25: 121-130.

Nguyen-Le, X.K., Q.T. Nguyen, F. Gobeil, D. Jukic, L. Chrétien and D. Regoli, 1996. Neurokinin receptors in the guinea pig ileum. Pharmacology, 52: 35-45.
Okpako, D.T. and Y.O.O. Taiwo, 1984. Cyclo-oxyginase inhibitors antagonize indirectly evoked contractions of the guinea-pig isolated ileum by inhibiting acetylcholine release. Br. J. Pharm., 82: 577-585.

Paton, D.M., 1968. The contractile response of the isolated rat uterus to noradrenaline and 5hydroxytryptamine. Eur. J. Pharmacol., 3: 310-315.

Rand, M.J. and C.G. Li, 1993. Modulation of acetylcholineinduced contractions of the rat anococcygeus muscle by activation of nitrergic nerves. Br. J. Pharmacol., 110: 1479-1482.

Reddy, J.S., P.R. Rao and M.S. Reddy, 2002. Wound healing effects of Heliotropium indicum, Plumbago zeylanicum and Acalypha indica in rats. J. Ethnopharmacol., 79: 249-251.

Rosenfeld, G.C. and D.S. Loose, 2006. Pharmacology. 4th Edn., Lippincott Williams and Wilkins, USA, pp: 35.

Sofowora, A., 1993. Screening Plants for Bioactive Agents. In: Medicinal Plants and Traditional Medicine in Africa, Sofowora, A. (Ed.). 2nd Edn. Spectrum Books Ltd., Ibadan, Nigeria, pp: 134-156.

Sonoyama, K., R. Fujiwara and T. Kasai, 2000. Non-effect of hexamethonium, a ganglionic blocker, on the response of ileal apolipoprotein A-IV mRNA following a massive small bowel resection in rats. Biosci. Biotechnol. Biochem., 64: $1282-1284$.

Srinivas, K., M.E.B. Rao and S.S. Rao, 2000. Antiinflammatory activity of Heliotropium indicum linn. and Leucas aspera spreng. in albino rats. Ind. J. Pharmacol., 32: 37-38.

Stief, C., W. Diederichs, F. Benard, R. Bosch, S. Aboseif, T.F. Lue and E.A. Tanagho, 1989. Possible role for acetylcholine as a neurotransmitter in canine penile erection. Urol. Int., 44: 357-363.

Trease, G.E. and W.C. Evans, 1989. A textbook of pharmacognosy. Bailliere Tindall Ltd., London, pp: 71-98.

Udupa, A.L., G.M. Rao and D.R. Kulkarni, 1989. Wound healing profile of Septilin. Indian J. hysiol.,Pharmacol., 33: 39-42.

Vargas, V.M., D. Torres, F. Corona, M. Vergara, L.E. Gomez, R. Delgado-Lezama and R. Cueva-Rolon, 2004. Cholinergic facilitation of erection and ejaculation in spinal cord-transected rats. Int. J. Impot. Res., 16: 86-90.

Zhao, X.L., M.Y. Chan and C.W. Ogle, 1989. The identification of pyrrolizidine alkaloid containing plants. Am. J. Chin. Med., 17: 71-78. 